\title{
ŠKODLJIVI ORGANIZMI IN ŠKODLJIVI DEJAVNIKI NA SADIKAH GOZDNEGA DREVJA V OBDOBJU 1997-2018
}

\section{PESTS, DISEASES AND HARMFUL ABIOTIC FACTORS AFFECTING FOREST TREE SEEDLINGS IN THE PERIOD 1997-2018}

\author{
Peter SMOLNIKAR ${ }^{1}$, Barbara PIŠKUR², Nikica OGRIS ${ }^{3}$ \\ (1) Gozdarski inštitut Slovenije, peter.smolnikar@gozdis.si \\ (2) Gozdarski inštitut Slovenije, barbara.piskur@gozdis.si \\ (3) Gozdarski inštitut Slovenije, nikica.ogris@gozdis.si
}

\begin{abstract}
IZVLEČEK
Škodljivi organizmi (ŠO) in abiotski škodljivi dejavniki (ŠD) na sadikah gozdnega drevja v gozdnih drevesnicah resno otežujejo vzgojo zdravih in kakovostnih sadik. Za preučitev pomembnejših in najpogosteje pojavljajočih se ŠO in ŠD smo analizirali letne zapisnike o zdravstvenih pregledih iz 18 gozdnih drevesnic v obdobju 1997-2018. Rezultati so pokazali, da so poškodbe v 68 \% zabeleženih primerov posledica delovanja patogenih gliv, v 29 \% primerih žuželk ter v 1,1 \% abiotskih dejavnikov. Poškodbe so bile zabeležene na 45 različnih rodovih drevesnih in grmovnih vrst, in sicer največkrat na rodovih Quercus $(24,1$ \%) in Pinus (17,5 \%), najpogostejše poškodbe so bile na listih oziroma iglicah (64,0 \%). Najpogosteje beležene bolezni so bile pepelovke (Erysiphe sp.), največ različnih ŠO in ŠD pa se je pojavljalo na borih (Pinus sp.). Poškodovanost sadik je bila običajno nizka (do 10 \%), vendar je močno variirala med leti. Za pridelovanje kakovostnih in zdravih sadik je ključen celosten pristop pri varstvu in vzgoji sadik.
\end{abstract}

Ključne besede: škodljiv organizem, bolezen, poškodovanost, sadika, semenka, mlada rastlina, drevesnica, Slovenija

\begin{abstract}
Pests and diseases together with harmful abiotic factors present a serious problem for the production of healthy and vital forest tree seedlings. In order to examine the most important and most frequently occurring harmful abiotic and biotic factors, we analyzed the annual reports of health surveys from 18 forest nurseries in the period 1997-2018. The results revealed that the observed injuries were caused by pathogenic fungi in $68 \%$ of cases, insects in $29 \%$ of cases and abiotic factors in $1.1 \%$ cases. Injuries occurred on 45 different tree and shrub genera, with Quercus sp. and Pinus sp. being the most frequently damaged (24.1\% and $17.5 \%$, respectively). Damage was frequently observed on leaves or needles (64.0\%). The most commonly reported diseases were powdery mildews (Erysiphe sp.). The greatest variability in the number of pests and diseases appeared on pines (Pinus sp.). Damage to planting stock usually occurred at low intensity (up to $10 \%$ ) but varied considerably during the period. The production of quality and healthy planting stock requires a holistic approach to seedling care.
\end{abstract}

Key words: harmful organism, disease, damage, planting stock, seedling, young plant, nursery, Slovenia

GDK 232.41

Prispelo / Received: 30. 9. 2019

DOI 10.20315/ASetL.120.4

Sprejeto / Accepted: 14.11. 2019

1 UVOD

1 INTRODUCTION

Pridelava sadik za obnovo gozdov poteka v gozdnih drevesnicah. Slovenija je leta 1993 sprejela Zakon o gozdovih $^{1}$ (Ur. l. RS št. 30/93), v katerem je opredeljena strategija sonaravnega gospodarjenja, ta pa narekuje obnovo gozdov predvsem z naravno pomladitvijo. Sadnja v gozdovih je bila vezana predvsem na sanacijo po ujmah (Vilhar in sod., 2013) in izvedbo premen (Gajšek in sod., 2014; Poročilo Zavoda..., 2019). Poraba sadik je bila od leta 1945 do leta 1993 dokaj stalna (10 sadik/

Spremembe in dopolnitve so objavljene v Uradnem listu RS,

št. 56/99 - ZON, 67/02, 110/02 - ZGO-1, 115/06 - ORZG40,

110/07, 106/10, 63/13, 101/13 - ZDavNepr, 17/14, 24/15,

9/16 - ZGGLRS in 77/16. ha vseh gozdov), strm upad pa je bil zabeležen po letu 1993 (1,6 sadike/ha); ta upad se je nadaljeval do leta 2014 (0,4 sadik/ha), ko je bilo doseženo dno (Perko, 2014). V zadnjih letih, ko so gozdove prizadele velikopovršinske ujme, je potreba po zasaditvi ogolelih površin narasla (Westergren in sod., 2017) in v letu 2018 je poraba sadik narasla na 0,9 sadike/ha (Poročilo Zavoda..., 2019). V Sloveniji smo v preteklosti imeli več gozdnih drevesnic; leta 1966 jih je bilo 83, od tega je bilo 15 sodobnih drevesničarskih obratov (Perko, 2014), leta 2004 je bilo gozdnih drevesnic 11, v letu 2018 pa smo imeli le še štiri gozdne drevesnice (Zapisniki o..., 2018). Poleg upadanja potreb po sadikah v zadnjih dveh desetletjih so drevesnice pestile tudi težave ob vzgoji sadik, 
predvsem bolezni in škodljivci, ki se pojavljajo ob pridelavi in vzgoji sadik gozdnega drevja.

Sadike v drevesnicah in gozdovih so večkrat izpostavljene stresu, ki ga povzročajo škodljivi biotski in/ ali abiotski dejavniki, ki v večini primerov delujejo $\mathrm{v}$ sinergiji (Cram in Dumroese, 2012). Primeri abiotskih dejavnikov so med drugim neustrezna lega, tla, pomanjkanje hranil, primanjkljaj ali presežek vode, količina svetlobe, toplote, veter, ki oslabijo mlado rastlino (sadiko), ta pa je posledično dovzetna za nadaljnjo okužbo z glivami in napad škodljivcev. Večino poškodb na sadikah v drevesnicah povzročajo glive (Maček, 2008) in žuželke (Jurc, 1996).

Škodljivci na sadikah povzročajo vrsto poškodb, ki vplivajo na vitalnost in preživetje sadik (Cram in Dumroese, 2012). Ukrepi, ki so na voljo drevesnicam ob pojavu Šo, so odvisni od patogenosti Šo, možnosti njegovega širjenja in zakonodajnih zahtev: npr. najdba karantenskega ŠO v drevesnici pomeni uničenje sadik, pojav nekaterih gospodarskih ŠO, ki se v drevesnicah pojavljajo redno, pa lahko omejimo z uporabo fitofarmacevtskih sredstev (Jurc, 2000). Preventivno se drevesničar lahko delno zavaruje $\mathrm{z}$ rednimi pregledi okolice drevesnice in rastlin samih ter omejitvami obiska nepooblaščenih oseb (Dumroese, 2012). Ob presajanju se pojavi šok za sadike, stres pa povzroči, da so sadike še bolj dovzetne za različne okužbe ter se težje branijo pred ŠO (Crist in Schoeneweiss, 1975). Zato so za uspešno sadnjo (pogozditev) ključnega pomena zdravstveno stanje sadik, pravilna manipulacija, sadnja in tudi nega v prvih letih po sadnji (Jurc, 1996).

Za vse objekte pridelave sadik za uporabo v gozdovih je po Zakonu o zdravstvenem varstvu rastlin (Ur. l. RS, št. 62/07), Pravilniku o pogojih za registracijo imetnikov določenih rastlin, rastlinskih proizvodov in nadzorovanih predmetov za namene zdravstvenega varstva rastlin in o pogojih za izdajanje rastlinskih potnih listov (Ur. l. RS, št. 93/2001) in Pravilniku o obveznem zdravstvenem pregledu posevkov in objektov, semena in sadilnega materiala kmetijskih in gozdnih rastlin ${ }^{2}$ (Ur. l. SFRJ, št. 52/86 in 3/87) obvezen letni pregled gozdnih drevesnic, ki ga opravlja Gozdarski inštitut Slovenije s svojimi s strani Uprave za varno hrano, veterinarstvo in varstvo rastlin pooblaščenimi fitosanitarnimi pregledniki. Fitosanitarne preglede v gozdnih drevesnicah se opravijo dvakrat na leto, in sicer prvi pregled od 1. 6. do 31. 7., drugi pregled pa pred sprostitvijo sadilnega materiala v promet oziroma od 1. 9. do 31. 10. Po pregledu gozdne drevesnice pooblaščeni fitosanitarni preglednik sestavi zapisnik o zdravstve-

$\overline{2}$ V 96. členu ZZVR-1 je ta pravilnik v uporabi do izdaje novega pravilnika. nem stanju, po drugem pregledu v tekočem letu pa izda še spričevalo, ki je pogoj za izdajo rastlinskih potnih listov in omogoča promet s sadikami (Hauptman, 2009). Izpolnjeni zapisniki o obveznem zdravstvenem pregledu kmetijskih posevkov za pridelovanje semena, objektov za pridelovanje gozdnega semena in objektov za pridelovanja trajnic so pomemben vir informacij o pojavljanju Šo na sadikah. Pomanjkljivost zapisnikov je v obveznem beleženju le karantenskih in gospodarskih ŠO (obveznih po Direktiva Sveta..., 2000; Pravilnik o..., 1987), ne pa vseh, ki so se pojavili (so bili odkriti) v drevesnici , čeprav se jih v praksi običajno tudi zavede. Še boljši vir za raziskavo bi zato bile knjige o obveznih zdravstvenih pregledih, ki jih hranijo drevesnice, ker so tam navadno navedeni tudi drugi škodljivi dejavni$\mathrm{ki}$, vendar je s propadom mnogih drevesnic dostopnost do teh knjig otežena. V pričujoči analizi smo pregledali podatke o pojavnosti ŠO in ŠD na sadikah gozdnega drevja v gozdnih drevesnicah v obdobju od 1997 do 2018. Dobljene rezultate smo nato primerjali z rezultati pregledov bolezni drevesnic do leta 1996 (Jurc, 1996).

\section{METODE}

\section{METHODS}

Analiza pojavljanja bolezni na sadikah gozdnega drevja je zajemala zbiranje podatkov po različnih podatkovnih zbirkah in arhivih in njihovo digitalizacijo. Glavni vir podatkov o pojavu bolezni in škodljivcih sadik lesnatih rastlin $v$ gozdnih, okrasnih in topolovih drevesnicah so bila: i) letna poročila o zdravstvenih pregledih sadik v gozdnih, okrasnih in topolovih drevesnicah in ob pregledu izpolnjeni Zapisniki o obveznem zdravstvenem pregledu kmetijskih posevkov za pridelovanje semena, objektov za pridelovanje gozdnega semena in objektov za pridelovanja trajnic; ii) javna poročila in elaborati Poročevalske, prognostičnodiagnostične službe za gozdove (PPD).

$\mathrm{V}$ našo analizo je bilo vključenih 18 gozdnih drevesnic (preglednica 1). Iz zbranih podatkov smo izračunali frekvenco, mediano in druge parametre pojavljanja ŠO in abiotskih škodljivih dejavnikov na sadikah gozdnega drevja. $Z$ analizo podatkov smo ugotovili najpogosteje prizadeto drevesno vrsto, drevesno vrsto, ki je gostitelj največ Šo, del rastline, ki je največkrat poškodovan, in stopnjo prizadetosti.

S primerjavo dveh obdobij, tj. 1962-1996 (Jurc, 1996) in 1997-2018, ki zajemata različno število let, smo s preračunom števila odkritih škodljivih organizmov na leto in drevesnico odkrili podobnosti/razlike med obravnavanimi obdobji, pri čemer smo v obdobju 1997-2018 upoštevali število let obratovanja dreve- 
Preglednica 1: Seznam drevesnic, njihova okvirna velikost, leto zadnjega poročila o zdravstvenem pregledu in seznam manjkajočih poročil v obdobju 1997-2018
Table 1: List of nurseries, their size, the year of the first and last report of corresponding health surveys and the list of missing reports in the period 1997-2018

\begin{tabular}{|c|c|c|c|c|}
\hline $\begin{array}{l}\text { Št. } \\
\text { No. }\end{array}$ & $\begin{array}{l}\text { Drevesnica } \\
\text { Nursery }\end{array}$ & $\begin{array}{l}\text { Velikost (ha) } \\
\text { Size (ha) }\end{array}$ & $\begin{array}{l}\text { Leto zadnjega poročila } \\
\text { Year of the last report }\end{array}$ & $\begin{array}{l}\text { Manjkajoča poročila } \\
\text { Missing reports }\end{array}$ \\
\hline 1 & Hraščica - GG Murska Sobota & 2,0 & 1999 & \\
\hline 2 & lžakovci - GG Murska Sobota & 3,5 & 2018 & 2003 \\
\hline 3 & Pinus - Kočevje & 5,7 & 1999 & \\
\hline 4 & Kostanjevica - HPG Brežice & 3,4 & 2007 & 2003, 2004, 2005 \\
\hline 5 & Lovrenc na Pohorju - Omorika & 6,5 & 2002 & \\
\hline 6 & Markovci - semesadike Mengeš & 11,7 & 2014 & 2003 \\
\hline 7 & Medvedica - Alojz Črnič & 0,8 & 2002 & \\
\hline 8 & Mengeš - Semesadike Mengeš & 36,0 & 2009 & 2003 \\
\hline 9 & Polana - GG Murska Sobota & 2,2 & 2018 & 2003 \\
\hline 10 & Radvanje - Semesadike Mengeš & 10,0 & 2008 & 2003 \\
\hline 11 & Rimš - HPG Brežice & 10,0 & 2012 & 2003 \\
\hline 12 & Tišina - Semesadike Mengeš & 15,0 & 2014 & 2003 \\
\hline 13 & Štivan - Štivan d.o.o. & 10,5 & 2018 & 2003 \\
\hline 14 & Vrbina - HPG Brežice & 6,0 & 2012 & 2003 \\
\hline 15 & HPG Brežice - sedež & 0,4 & 2000 & \\
\hline 16 & Muta - Omorika & 16,0 & 2018 & 2003 \\
\hline 17 & Ponoviče - Gozd d.d. Ljubljana & 0,5 & 2000 & \\
\hline 18 & Vodice - Ivan Tušek & 1,0 & 2002 & \\
\hline
\end{tabular}

snice glede na leto zadnjega poročila (preglednica 1). Medsebojno smo primerjali le drevesnice, ki so bile obravnavane že v obdobju 1962-1996 (14). Za test razlik (podobnosti) smo uporabili neparametrični Mann-Whitney U-test.

\section{REZULTATI}

\section{RESULTS}

V obravnavanih gozdnih drevesnicah je bilo zabeleženih 119 različnih bolezni in škodljivih dejavnikov. Najpogostejši dejavniki, ki so povzročali poškodbe na sadikah gozdnih drevesnih vrst v drevesnicah v analiziranem obdobju (1997-2018), so bile glive (68 \%), žuželke (29 \%) ter abiotski dejavniki (1,1\%). Vse druge poškodbe so bile posledica delovanja drugih organizmov (npr. glodavci, polži, druge živali) oziroma so bile posledica napak pri delu s sadikami (preglednica 2). Poškodbe na sadikah so se pojavljale na 45 različnih rodovih drevesnih in grmovnih vrst. ŠO in poškodbe zaradi abiotskih dejavnikov so bili največkrat zabeleženi na rodovih Quercus $(24,1 \%)$, Pinus (17,5\%), Picea $(8,7$ $\%)$, Tilia (7,3 \%) in Acer (6,3 \%). Največ poškodb se je pojavljalo na listih/iglicah $(64,0 \%)$, vejah $(14,4 \%)$ in poganjkih (12,6\%). Najpogostejše poškodbe so bile posledica (glede na frekvenco pojavljanja) bolezni iglic in listja s $57,2 \%$, sledijo poškodbe zaradi defoliatorjev z $9,2 \%$ in floemofagov z $9,7 \%$.
Frekvenca pojavljanja vrst ŠO in škodljivih dejavnikov (ŠD) je bila različna. Najvišjo frekvenco so imele pepelovke (Erysipheaceae), ki so bile zabeležene 195krat oz. v 22,0 \% primerov, med njimi se je največkrat pojavila hrastova pepelovka (Erysiphe alphitoides), pogosteje sta bili zabeleženi tudi cerkosporna lipova listna pegavost (Paracercosporidium microsorum) v 64 primerih oz. 7,2 \% in češnjeva listna pegavost (Blumeriella jaapii) v 56 primerih oz. 6,3\%.

Na sadikah iglavcev je bilo zabeleženih 52 različnih ŠO in ŠD, na sadikah listavcev pa 84. Določeni ŠO in ŠD, ki so bili prepoznani kot vzrok poškodb na sadikah, so

Preglednica 2: Frekvenca pojavljanja škodljivih organizmov (ŠO) in škodljivih dejavnikov (ŠD) v obdobju 1997-2018

Table 2: Frequencies of different harmful factors from 19972018

\begin{tabular}{|c|c|}
\hline $\begin{array}{c}\text { Škodljivi dejavnik / organizem } \\
\text { Harmful factor / organism }\end{array}$ & $\begin{array}{c}\text { Frekvenca (\%) } \\
\text { Frequency (\%) }\end{array}$ \\
\hline abiotski dejavnik & 1,1 \\
\hline bakterije & 0,2 \\
\hline človek & 0,3 \\
\hline pršice & 0,5 \\
\hline glive & 68,0 \\
\hline polži & 0,1 \\
\hline sesalec & 0,5 \\
\hline žuželka & 29,0 \\
\hline neznan povzročitelj & 0,3 \\
\hline
\end{tabular}




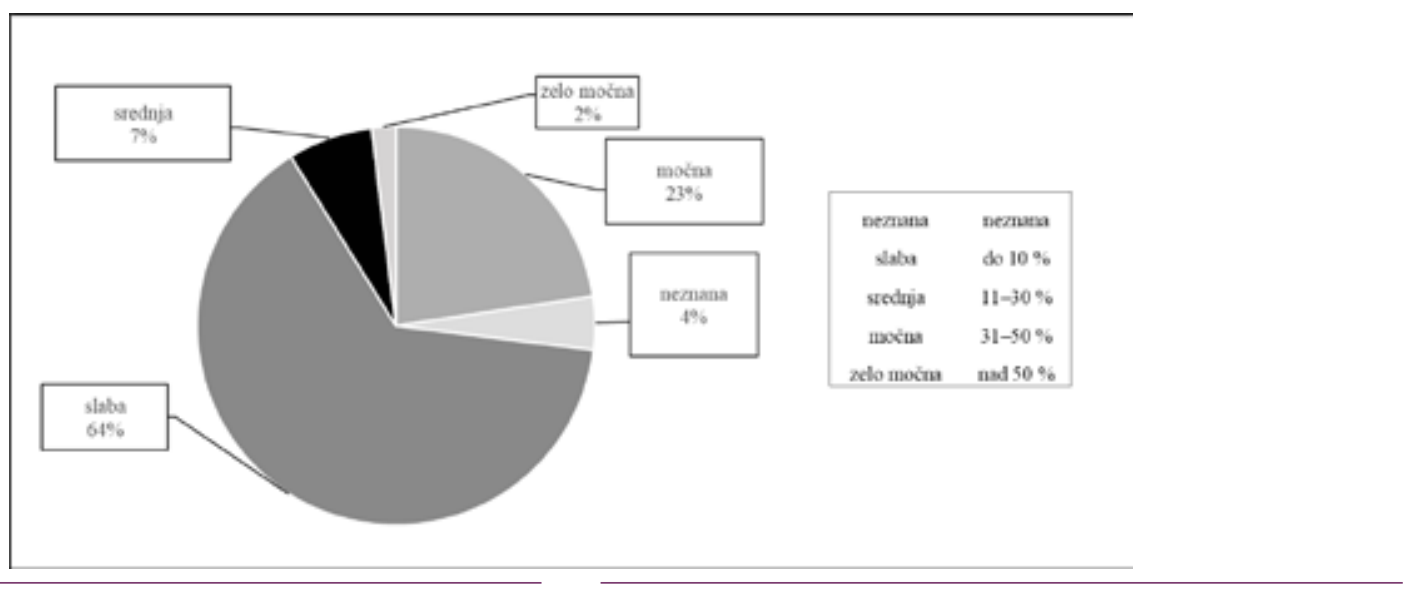

Slika 1: Intenziteta poškodovanosti sadik v drevesnicah

se pojavljali tako pri listavcih kot iglavcih (npr. izpad ob presajanju in manipulaciji s sadikami, sušni stres). Glede na pojavnost (frekvenco) ŠO in ŠD po drevesnih vrstah je bilo največ različnih vrst Šo in ŠD zabeleženih na borih (Pinus sp.) (25), smrekah (Picea sp.) (13), hrastih (Quercus sp.) (12) in topolih (Populus sp.) (11).

Škodljivi organizmi in dejavniki poškodujejo sadike $\mathrm{v}$ različnih intenzitetah ter v različnih obdobjih. Sadike $\mathrm{v}$ drevesnicah zato niso enako močno prizadete (slika 1). Največ sadik (64\%) je bilo rahlo (slabo) prizadetih (poškodovanost do $10 \%$ ), dobra petina (23 \%) je močno prizadetih (poškodovanost 31-50 \%) (slika 1). Poškodovanost (intenziteta poškodb in pojav ŠO in ŠD) je močno variirala med letnimi časi, leti in drevesnimi vrstami, srednja poškodovanost (mediana) je bila nizka (oz. slaba), tj. $5 \%$.

\subsection{Primerjava med dvema časovnima obdobjema}

3.1 Comparison between the two periods

Primerjava bolezni, škodljivcev in škodljivih dejavnikov v gozdnih drevesnicah v obdobjih 1962-1996 in
Fig. 1: Damage intensity on nursery seedlings

1997-2018 je pokazala, da obstajajo nekatere podobnosti: najpogosteje pojavljajoči se škodljivi organizmi in dejavniki (68 \%) so glive, drugo mesto (29\%) zavzemajo žuželke, podobno je bilo tudi v preteklem analiziranem obdobju (1962-1996) (glive 63,5 \%, žuželke 36,2 \%). V obdobju 1997-2018 je bilo med drevesnicami zabeleženo statistično značilno $(Z=-2,068$; $p<0,05)$ različno število škodljivih organizmov in dejavnikov kot v preteklem obdobju (1962-1996) (slika 2). Skupno je bilo v obdobju 1997-2018 zabeleženih več različnih rodov bolezni (51, prej 44) in škodljivcev (44, prej 37). Največkrat zabeležene bolezni v drevesnicah so skozi vsa analizirana leta skoraj vedno iste (Erysiphe sp., Lophodermium sp., Blumeriella jaapii in Paracercosporidium microsorum). Žuželke, ki povzročajo poškodbe, pa so največkrat smrekove uši ( $\mathrm{Sa}$ cchiphanthes sp.), lepenci (Chrysomelidae) in topolovi kozlički (Saperda sp.).

V obeh obdobjih se je največ različnih Šo pojavljalo na iglavcih, največkrat zabeležen ŠO tj. pepelovke (Erysiphaceae), so se pojavljale na hrastih (Quercus

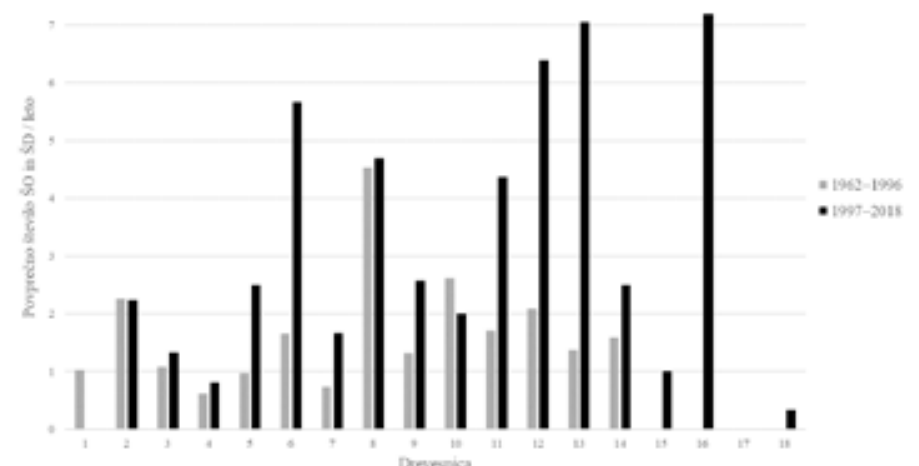

Slika 2: Primerjava povprečnega števila zabeleženih škodljivih organizmov in dejavnikov v različnih gozdnih drevesnicah v dveh analiziranih obdobjih: 1962-1996 in 1997-2018. Šifra drevesnice je podana v preglednici 1.
Fig. 2: Comparison of mean number of recorded pests in different forest nurseries in the periods 1962-1996 and 19972018. Forest nursery No. is given in Table 1. 
sp.). Med največkrat prizadetimi deli rastlin so bile iglice/listi in poganjki, ki so jih ŠO in ŠD prizadeli v 76,6 $\%$ primerih (prej 77,8 \%). Starosti prizadetih rastlin ni bilo mogoče primerjati, ker podatki o starosti sadik $\mathrm{v}$ zapisnikih o zdravstvenih pregledih sadik niso bili navedeni. Nasprotno pa nismo mogli napraviti primerjave intenzitete poškodovanosti, ker ta za obdobje do 1996 ta ni posebej navedena.

\section{RAZPRAVA IN SKLEPI}

\section{DISCUSSION AND CONCLUSIONS}

Med boleznimi, ki se pojavljajo na sadikah gozdnega drevja v slovenskih gozdnih drevesnicah in gozdovih, so bile v obdobju 1997-2018 najpogostejše pepelovke (Erysiphaceae) in razni osipi (Lophodermium sp., Cyclaneusma sp.). Zadnjih nekaj let je v gozdovih pomlajevanje poljskega in velikega jesena zmanjšano zaradi jesenovega ožiga, bolezni, ki jo povzroča gliva Hymenoscyphus fraxineus (Ogris in Jurc, 2017; Poročilo Zavoda..., 2019), vendar v podatkih, ki so bili osnova za pregled bolezni in škodljivcev v gozdnih drevesnicah, te glive in bolezni skoraj ni zaznati (zabeležena le štirikrat), predvsem zato, ker njenega odkritja v drevesnici zaradi že omenjenih zahtev ni nujno zabeležiti v Zapisnik. Drugi razlog za malo zabeležk te bolezni je verjetno tudi $v$ tem, da se sadik jesena v gozdnih drevesnicah, ravno zaradi izredne patogenosti te bolezni, od leta 2010 ne vzgaja več (Poročilo Zavoda..., 2019). Apotecije gliva oblikuje tudi na odmrlem lesu, tako da lahko že nekaj okuženih sadik povzroči novo žarišče bolezni (Kirisits in sod., 2012). Velika nevarnost za pridelavo sadik v gozdnih drevesnicah so trenutno tudi glivolike alge iz rodu Phytophthora, ki se s sadilnim materialom in ostanki zemlje prenašajo v gozd (Ogris in Jurc, 2017), kjer lahko povzročijo odmiranje dreves in posledično vplivajo na spremenjeno strukturo gozdov (Hansen, 2015; Grunwald in sod., 2019; Peters in sod., 2019; Trajber in sod., 2019). V Sloveniji še ni bila napravljena raziskava o pojavljanju teh organizmov v gozdnih drevesnicah, so pa v nedavni pan-evropski študiji Jung in sod. (2016) pregledali 732 drevesnic ter 2525 gozdnih nasadov s sadikami iz gozdnih drevesnic ter pri več kot $90 \%$ pregledanih drevesnic ter pri $67 \%$ gozdnih nasadih odkrili fitoftore. Med 68 različnimi vrstami fitoftor so zaznali večino takih vrst, ki so prepoznane kot invazivne oziroma so bile sploh prvič poročane v Evropi. Na ravni Evropske unije naj bi tako v obdobju 1990-2010 pri novih pogozditvah petih milijonov hektarov površine uporabili sadike, ki so bile okužene s fitoftorami (Jung in sod., 2016). Pri pregledu gozdnih drevesnic v obdobju 1997-2018 smo vrste iz rodu Phytophthora zaznali štirikrat, od tega so bile tri najdbe vrste $P$. ramorum, ki so bile povezane $\mathrm{z}$ vnosom okuženih rastlin v Slovenijo. Vse okužene rastline so bile uničene, saj je vrsta $P$. ramorum karantenska vrsta, ki je regulirana z Odločbo Komisije (2002/757/ES, s spremembami) o začasnih nujnih ukrepih za preprečevanje vnosa glive Phytophthora ramorum v Skupnost in njenega širjenja v Skupnosti. V gozdovih omenjenega Šo nismo zaznali, kljub temu, da poteka letni program preiskav na območju celotne Slovenije (Programi preiskav..., 2019). Kakšno je stanje v gozdnih drevesnicah in gozdovih glede pojavljanja vrst Phytophthora ni podrobno raziskano, se pa rod Phytophthora redno pojavlja ob uvozu sadik (predvsem okrasnih vrst rodu Rhododendron in Viburnum) (Žerjav in Benko Beloglavec, 2013). V zadnjem času pri posameznih pregledih na terenu in analizah vzorcev opažamo zaznavamo vrste iz rodu Phytophthora, ki imajo najverjetneje vpliv na slabše zdravstveno stanje določenih gozdnih sestojev Sloveniji (npr. P. alni v sestojih črne jelše v Črnem Logu (Piškur in sod., 2016) in P. plurivora v sestojih hrastov v Cigonci (Ogris in sod., 2018)).

Škodljive organizme v tuji literaturi običajno delijo glede na gostitelja (iglavec/listavec) in povzročitelja (gliva/žuželka) ter dodatno dejavnike okolja (Sutherland in sod., 1989; Cram in Dumroese, 2012). Največ različnih skupin bolezni se v vseh primerih pojavlja na iglavcih (Lilja in sod., 2010; Cram in Dumroese, 2012). Na Finskem 99 \% sadik vzgojijo v kontejnerjih, glavne bolezni običajno zatirajo s fungicidi, med najbolj perečimi problemi iglavcev pa na Finskem prepoznavajo bolezen, ki jo povzroča gliva Gremmeniella abietina. $\mathrm{Na}$ Finskem so v preteklosti imeli pri predelavi sadik velike težave z odmiranjem koreninskega sistema (Rhizoctonia sp.), a so z uvedbo higienskih ukrepov te težave močno zmanjšali (Lilja in sod., 2010).

Pojavnost škodljivih dejavnikov in škodljivih organizmov je po drevesnicah zelo različna, največkrat so sicer zabeleženi v drevesnicah Omorika (151), Štivan (148), Tišina (115) in Markovci (102) (glej: priloga 1). Vendar to ne odseva boljših ali slabših praks drevesnic, tako da kakršna koli primerjava drevesnic po tem kriteriju ni verodostojna. Za verodostojno primerjavo bi morali upoštevati vsaj velikost drevesnic ter še pomembneje število različnih posajenih vrst v vsakem letu, te kriterije pa tudi ponderirati. Skratka, namen analiz ni bil rangiranje drevesnic, ampak preučitev nabora škodljivih organizmov, ki se pojavljajo v slovenskih gozdnih drevesnicah. Gozdnim drevesnicam do pred kratkim ni kazalo najbolje, saj je površina obnovljenih gozdov s setvijo in saditvijo od leta 1997 do 2014 z 900 ha/letno upadla na 307 ha/letno, po letu 2014 pa je opažen trend povečane porabe sadik (We- 
stergren in sod., 2017) predvsem na račun ujm in sprejetih dokumentov, ki predvidevajo ukrepe za sanacijo gozdov (Uredba o ukrepih..., 2016). Zaradi stagnacije gozdnega drevesničarstva oz. propada večine gozdnih drevesnic je tudi primerjava pojavnosti ŠO po drevesnicah (slika 2) in kakršnokoli sklepanje o boljših ali slabših praksah določenih drevesnic popolnoma neverodostojno in nesmiselno, ker so le tri drevesnice (Ižakovci (2), Polana (9) in Štivan (13)) zastopane v vseh letih primerjave.

Bolezni in škodljivci v gozdnih drevesnicah so in bodo vedno obstajali, njihovo patogenost in obsežnost poškodb pa lahko poleg uporabe določenih fitosanitarnih sredstev (Pravilnik o varstvu gozdov, Ur. l. RS, št. 31/16) omejimo tudi s preprostimi ukrepi, ki zmanjšujejo stres pri sadikah (Cram in Dumroese, 2012). To vključuje ustrezno higieno (znotraj in zunaj drevesnice), odstranjevanje bioloških odpadkov in sadik, ki niso bile dane v promet (Jurc, 1996), razkuževanje kontejnerjev pred sadnjo (Lilja in sod., 2010) ter pravilno izbiro same mikrolokacije sajenja glede na drevesno vrsto (Grecs, 1996). Z globalno trgovino in spremenjenimi vremenskimi razmerami se tako gozdovi kot gozdno drevesničarstvo spopadajo z novimi izzivi, kot so pojav novih bolezni in škodljivcev (Lilja in sod., 2010; Roy in sod., 2014) ter iskanje in promocija drevesnih vrst, ki bodo odpornejše in uspešnejše v novih podnebnih razmerah. Zaradi stagnacije drevesničarstva je večina drevesnic $v$ preteklosti propadla, nekatere preživele pa se iz situacije rešujejo $\mathrm{z}$ dodatnim okrasnim programom (Hauptman, 2009), ki pa je močno povezan $\mathrm{z}$ mednarodno trgovino s sadilnim materialom in posledično pomeni nevarnost za vnos novih škodljivih organizmov (Tavzes, 2009). Konec leta 2019 bo v veljavo stopila tudi nova zakonodaja Evropske unije s področja zdravja rastlin, ki vpeljuje nove definicije in skupine škodljivih organizmov in spreminja določene zahteve, ki se navezujejo tudi na pridelavo sadik gozdnega drevja. Opravljanje zdravstvenih pregledov gozdnih drevesnic v Sloveniji poteka po Pravilniku o obveznem zdravstvenem pregledu posevkov in objektov, semena in sadilnega materiala kmetijskih in gozdnih rastlin iz leta 1986. Zasnova pravilnika je še vedno aktualna, bi pa bilo treba pravilnik posodobiti v navezavi z aktualnimi nacionalnimi in evropskimi predpisi.

\section{POVZETEK}

\section{SUMMARY}

Forestry has been facing various unpredictable conditions in recent years. Extreme weather events have caused large forest stand gaps, which need to be reforested. Due to Slovenia's strategy of sustainable management of forests, reforestation is done mainly through natural regeneration. Consequently, the production of seedlings has declined, and the number of forest nurseries fell from 83 in 1966 to 11 in 2004 to only four in 2018. The production of seedlings is a sector with inherent risks associated with unpredictable demand for seedlings and regulatory requirements. These risks are further exacerbated by the detrimental environmental factors associated with seedling production. Damage in forest nurseries is caused by abiotic factors (wind, deficits or surpluses of macro and micro nutrients, the amount of light and water, hail) and pests and diseases (insects, fungi, viruses, parasitic galls), but sometimes damage is caused by the improper manipulation of seedlings or treatment with the wrong chemical substances. For all planting stock for use in forests, a statutory annual inspection of nurseries is conducted by authorized phytosanitary inspectors from the Slovenian Forestry Institute.

The aim of our research was to collect nursery data recorded by phytosanitary inspectors and Reporting, Prognostic and Diagnostic (RPD) service for forests on the most common pests occurring on forest seedlings in nurseries in the period 1997-2018. The main sources of data were annual reports on health surveys of seedlings in forests, ornamental and poplar nurseries, reports from the Reporting, Prognostic-Diagnostic Service for Forests, and reports on samples of seedlings received by the Laboratory for Forest Protection at the Slovenian Forestry Institute. The analysis included 18 forest nurseries. From the collected data, we calculated the frequency, median and other parameters of pests and harmful abiotic factors that occurred on the seedlings. The data analysis revealed the most commonly affected tree species, the tree species that is host to the highest number of pests, the part of the plant that is most often damaged and its damage intensity. In parallel, we also compared the frequencies of pest occurrence between the two analyzed periods.

The results showed that the injuries were caused by pathogenic fungi in $68 \%$ of cases, insects in $29 \%$ of cases and abiotic factors in $1.1 \%$ of cases. Injuries occurred on 45 different genera of tree and shrub species. Most damage was recorded on the genus Quercus (24.1\%) and Pinus (17.5 \%), and the most frequently damaged plant parts were leaves or needles (64.0\%). The most commonly reported diseases were powdery mildews (Erysiphe sp.). Pines (Pinus sp.) were hosts to the largest number of different harmful factors. Seedling damage usually occurred at a low level (up to $10 \%$ ) but varied considerably during the studied period. 
The parallel comparison of the two analyzed periods revealed many similarities, in both periods most of the injuries were caused by fungi, followed by insects and abiotic factors. The most commonly recorded diseases in nurseries were almost always the same throughout the analyzed years (Erysiphe sp., Lophodermium sp., Blumeriella jaapii and Paracercosporidium microsorum). The majority of different harmful factors occurred on conifers. The most frequently affected parts of plants were leaves, needles or shoots. Comparison of the damage intensity and age of affected seedlings between the two analyzed periods was not possible due to missing data. However, in the period 1997-2018, several different harmful biotic and abiotic factors (119, formerly 81) were present.

Natural disasters in recent years have increased the need for seedlings, and nurseries are currently unable to meet the demand. In addition to financial, legal, technical and technological factors, loss due to damage agents also complicates the production of quality seedlings. The most frequent diseases of seedlings are still caused by powdery mildew (Erysiphaceae) and various needlecast diseases (Lophodermium sp., Cyclaneusma sp.). Planting loss is also commonly caused by human factors, especially with respect to handling (manipulation) seedlings. The fungus Hymenoscyphus fraxineus, which threatens the regeneration of ash (Fraxinus sp.), was seldom recorded in the health surveys, as ash is not used for reforestation. Also, certain diseases are not recorded in the records because they are not on the checklist, although they may be present. Pathogens will always be present in nurseries, and the damage they cause can be minimized with chemical plant protection products, biopesticides or with simple hacks that reduce seedling stress (possibly also mycorrhizal fungi). Particular emphasis should be placed on hygiene, monitoring and disposal of bio-waste and affected seedlings.

\section{ZAHVALA}

\section{ACKNOWLEGMENTS}

Raziskava je nastala v okviru projekta Presoja uspešnosti obnove gozdov s sadnjo in setvijo v Sloveniji (V4-1819), ki ga financirata Ministrstvo za kmetijstvo, gozdarstvo in prehrano ter Javna agencija za raziskovalno dejavnost Republike Slovenije, in v okviru programske skupine Gozdna biologija, ekologija in tehnologija (P4-0107), ki jo financira Javna agencija za raziskovalno dejavnost Republike Slovenije. Za pregled in predloge izboljšav pričujočega prispevka se zahvaljujemo recenzentoma.

\section{VIRI}

\section{REFERENCES}

Cram M., Dumroese K. 2012. Mycorrhizae in Forest Tree Nurseries. V: Forest nursery pests. (Agriculture Handbook No. 680). Cram M., Frank M., Mallams K. (ur.). United States Departemnt of agriculture: $18-23$.

Crist C.R., Schoeneweiss D.F. 1975. The influence of controlled stresses on susceptibility of European white birch stems to attack by Botryosphaeria dothidea. Phytopathology, 65, 4: 369-373.

Direktiva Sveta 2000/29/ES z dne 8. maja 2000 o varstvenih ukrepih proti vnosu organizmov, škodljivih za rastline ali rastlinske proizvode, v Skupnost in proti njihovemu širjenju v Skupnosti. (UL L 169, 10. 7. 2000).

Dumroese K. 2012. Integrated Nursery Pest Management. V: Forest nursery pests. (Agriculture Handbook No. 680). Cram M., Frank M., Mallams K. (ur.). United States Departemnt of agriculture: 5-12.

Gajšek D., Jarni K., Lumbar A., Brus R. 2014. Premena odraslih borovih nasadov na Krasu s saditvijo avtohtonih listavcev. Gozdarski vestnik, 72, 9: 355-364.

Grecs Z. 1996. Obnova gozdov s saditvijo - korak k višji kakovostni ravni gozdarske operativne stroke. Zbornik gozdarstva in lesarstva, 51: 133-143.

Grünwald N., LeBoldus J., Hamelin R. 2019. Ecology and evolution of the sudden oak death pathogen Phytophthora ramorum. Annual Review of Phytopathology, 57: 301-321.

Hansen E.M. 2015. Phytophthora species emerging as pathogens of forest trees. Current Forestry Reports, 1, 1: 16-24.

Hauptman T. 2009. Zdravstveni pregledi gozdnih drevesnic. Strokovna naloga, Ljubljana, Gozdarski inštitut Slovenije: 36 str.

Jung T., Orlikowski L., Henricot B., Abad-Campos P., Aday A.G. in sod. 2016. Widespread Phytophthora infestations in European nurseries put forest, semi-natural and horticultural ecosystems at high risk of Phytophthora diseases. Forest Pathology, 46, 2: 134-163.

Jurc D. 2000. Obvladovanje najpomembnejših bolezni v gozdnih drevesnicah. Gozdarski vestnik, 58, 9: 370-376.

Jurc M. 1996. Bolezni in škodljivci sadik gozdnega drevja kot dejavnik kakovosti. Zbornik gozdarstva in lesarstva, 51: 175-188.

Kirisits T., Kritsch P., Kräutler K., Matlakova M., Halmschlager E. 2012. Ash dieback associated with Hymenoscyphus pseudoalbidus in forest nurseries in Austria. Journal of Agricultural Extension and Rural Development, 4, 9: 230-235.

Lilja A., Poteri M., Petäistö R.-L., Rikala R., Kurkela T., Kasanen R. 2010. Fungal diseases in forest nurseries in Finland. Silva Fennica, 44, 3: 525-545.

Maček J. 2008. Gozdna fitopatologija. Ljubljana, Zavod za gozdove Slovenije in Zveza gozdarskih društev Slovenije - Gozdarska založba: 448 str.

Odločba Komisije o začasnih izrednih fitosanitarnih ukrepih za preprečevanje vnosa škodljivega organizma Phytophthora ramorum Werres, De Cock \& Man in 't Veldsp. nov. v Skupnost in njenega Širjenja v Skupnosti. 2002. 2002/757/ES.

Ogris N., de Groot M., Piškur B., Brglez A. 2018. Poročilo o preskusu št. LVG 2018-159: sušenje doba v Cigonci https://www.zdravgozd.si/pdp_porocila_predogled.aspx?idgk=LVG2018159 (11. 9. 2019).

Ogris N., Jurc D. 2017. Vpliv bolezni in škodljivcev na obnovo gozdov. Gozdarski vestnik, 75, 4: 213-217.

Perko F. 2014. Gozdno drevesničarstvo na Kranjskem, v Dravski banovini in Sloveniji, njegov razvoj in propad. Gozdarski vestnik, 72, 9: 383-403.

Peters F.S., Wunderlich L., Metzler B. 2019. First report of Phytophthora cinnamomi in forest stands in Germany. Forest Pathology, 49, 2:1-3. 
Piškur B., Ogris N., Jurc D. 2016. Poročilo o preskusu št.: U2016004: jelševa sušica (Phytophthora alni subsp. multiformis). https://www.zdravgozd.si/pdp_porocila_predogled. aspx?idgk=U2016004 (11. 9. 2019).

Poročilo Zavoda za gozdove Slovenije o gozdovih za leto 2018. 2019. Pisek R., Poljanec A. (ur.). Ljubljana, Zavod za gozdove Slovenije: $135 \mathrm{str}$.

Pravilnik o pogojih za registracijo imetnikov določenih rastlin, rastlinskih proizvodov in nadzorovanih predmetov za namene zdravstvenega varstva rastlin, in o pogojih za izdajanje rastlinskih potnih listov. 2001. Ur. l. RS, št. 93/2001.

Pravilnik o varstvu gozdov. 2016. Ur. l. RS, št. 31/16.

Pravilnik o obveznem zdravstvenem pregledu posevkov in objektov, semena in sadilnega materiala kmetijskih in gozdnih rastlin. 1987. Ur. l. SFRJ, št. 52/86 in 3/87.

Programi preiskav za ugotavljanje navzočnosti škodljivih organizmov rastlin za leto 2019. 2019. Pajk P. (ur.). Ljubljana, Uprava Republike Slovenije za varno hrano, veterinarstvo in varstvo rastlin: $348 \mathrm{str}$

Roy B., Alexander H., Davidson J., Campbell F., Burdon J., Sniezko R., Brasier C. 2014. Increasing forest loss worldwide from invasive pests requires new trade regulations. The Ecological Society of America, 12, 8: 457-465.

Sutherland J., Shrimpton G., Sturrock R. 1989. Diseases and insects in British Columbia forest seedling nurseries. FRDA report, 065 93 str.

Tavzes B. 2009. Pregled nacionalnih predpisov in predpisov EU $s$ področja tujerodnih vrst. V: Zbornik s posveta Tujerodne vrste v Sloveniji, Ljubljana, 10. marec 2009. Kus Veenvliet J. (ur.). Ljubljana, Zavod Symbiosis: 24-32.

Priloga 1: Frekvenca pojavljanja ŠO po gozdnih drevesnicah v obdobju 1997-2018. V glavi stolpca je navedena št. drevesnice iz preglednice 1.
Trajber D., Ogris N., Jurc D., Piškur B. 2019. Problemi z jesenovim ožigom (Hymenoscyphus fraxineus) in jelševo sušico (Phytophthora alni) v severovzhodnem delu Slovenije. V: Izvlečki referatov 14. Slovenskega posvetovanja o varstvu rastlin z mednarodno udeležbo, Maribor 2019. Trdan S. (ur.). Društvo za varstvo rastlin Slovenije: $34-34$

Uredba o ukrepih za sanacijo in obnovo gozda po naravni nesreči žledu med 30. januarjem in 10. februarjem 2014 iz Programa razvoja podeželja Republike Slovenije za obdobje 2014-2020. 2016. Ur. l. RS, št. 3/16, 63/17, 71/18, 47/19.

Vilhar U., Kraigher H., Kutnar L., Simončič P., Grecs Z. 2013. Načrtovanje obnove gozda po velikih poškodbah. Gozdarski vestnik, 71, 1: 2-18.

Westergren M., Božič G., Kraigher H. 2017. Trendi v gozdnem semenarstvu in drevesničarstvu v Sloveniji. Gozdarski vestnik, 75, 4: 184-191.

Zakon o gozdovih. 1993. Ur. l. RS, št. 30/93.

Zakon o zdravstvenem varstvu rastlin. 2007. Ur. l. RS, št. 62/07, št. $36 / 10$ in $40 / 14$.

Zapisniki o zdravstvenih pregledih drevesnic do vključno leta 2018. 2018. Ljubljana, Gozdarski inštitut Slovenije (arhiv GIS - Zapisniki o zdravstvenih pregledih, 15. 4. 2019).

Žerjav M., Beloglavec Benko A. 2013. Deset let nadzora fitoftorne sušice vejic (Phytophthora ramorum) v Sloveniji. V: Zbornik predavanj in referatov 11 . Slovenskega posvetovanja o varstvu rastlin z mednarodno udeležbo, Bled, 5.-6. marec 2013. Trdan S., Maček J. (ur.). Društvo za varstvo rastlin Slovenije: 46-51.

Annex 1: Frequency of harmful organisms in forest nurseries in the period 1997-2018. In the table heading, No. of nursery from Table 1 is stated.

\begin{tabular}{|c|c|c|c|c|c|c|c|c|c|c|c|c|c|c|c|c|c|c|c|c|}
\hline ŠO/ simptom & 1 & 2 & 3 & 4 & 5 & 6 & 7 & 8 & 9 & 10 & 11 & 12 & 13 & 14 & 15 & 16 & 17 & 18 & Skupaj & Skupaj (\%) \\
\hline Acantholyda hieroglyphica & & & & & & 1 & & & & & & 3 & 2 & 1 & 2 & 2 & & & 11 & 1,3 \\
\hline Aceria macrorrhyncha & & & & & & & & & & & 2 & & & & & & & & 2 & 0,2 \\
\hline Aceria pseudoplatani & & & & & & & & & & & 2 & & & & & & & & 2 & 0,2 \\
\hline Adelgidae & & & & & & 1 & & & & & 2 & & 3 & & & & & & 6 & 0,7 \\
\hline Agrobacterium tumefaciens & & & & & & & & & & & & & & & & 1 & & & 1 & 0,1 \\
\hline Apethymus abdominalis & & & & & 1 & & & & 1 & & & 1 & & & & & & & 3 & 0,4 \\
\hline Apethymus braccatus & & & & & 1 & & & & 1 & & & 1 & & & & & & & 3 & 0,4 \\
\hline Apethymus sp. & & & & 1 & & & & & & & & & & & & & & & 1 & 0,1 \\
\hline Aphidoidea & & & & & & & & & & & & & & & & 1 & & & 1 & 0,1 \\
\hline Apiognomonia errabunda & & & & & & 2 & & & & 1 & & & & & & 1 & & & 4 & 0,5 \\
\hline Argyresthia thuiella & & & & & & & & 2 & & & & 2 & 1 & & & & & & 5 & 0,6 \\
\hline Armillaria sp. & & & & & & & & & & & & & 1 & & & & & & 1 & 0,1 \\
\hline Arvicola terrestris & & & & 2 & & & & & & & & & 2 & & & & & & 4 & 0,5 \\
\hline Blumeriella jaapii & & & & & & 13 & 1 & 2 & & 2 & & 17 & 3 & & & 18 & & & 56 & 6,5 \\
\hline Botrytis sp. & & & & & & & & & & & 1 & & & & & 1 & & & 2 & 0,2 \\
\hline Buprestidae & & & & & & & & & & 1 & & & 3 & & & & & & 4 & 0,5 \\
\hline Caliroa sp. & & & & & & 1 & & & 7 & & 2 & 2 & & & & 4 & & & 16 & 1,9 \\
\hline Cameraria ohridella & & & & & & & & 4 & & & & 2 & & & & & & & 6 & 0,7 \\
\hline Chrysomela populi & & 9 & & & & & & & & & & & & 2 & & & & & 11 & 1,3 \\
\hline Chrysomelidae & & 1 & & & & & & & & & & & & & & & & & 1 & 0,1 \\
\hline Cinara curvipes & & & & & & & & & & & & 1 & & & & & & & 1 & 0,1 \\
\hline Coleophora laricella & & & & & & & & & & & 1 & & & & & & & & 1 & 0,1 \\
\hline Cristulariella depraedans & & & & & & & 1 & & & & & & 5 & & & 6 & & & 12 & 1,4 \\
\hline Cronartium ribicola & & & & & & & & & & & 1 & 1 & 1 & & & 1 & & & 4 & 0,5 \\
\hline
\end{tabular}




\begin{tabular}{|c|c|c|c|c|c|c|c|c|c|c|c|c|c|c|c|c|c|c|c|c|}
\hline ŠO/ simptom & 1 & 2 & 3 & 4 & 5 & 6 & 7 & 8 & 9 & 10 & 11 & 12 & 13 & 14 & 15 & 16 & 17 & 18 & Skupaj & Skupaj (\%) \\
\hline Cryphonectria parasitica & & & & & & 3 & & & & 1 & & 5 & 2 & & & 3 & & & 14 & 1,6 \\
\hline Cryptodiaporthe populea & & 3 & & & & & & & & & & & & & & & & & 3 & 0,4 \\
\hline Cryptorhynchus lapathi & & 1 & & & & & & & & & & & & & & & & & 1 & 0,1 \\
\hline Cumminsiella mirabilissima & & & & & & & & & & & & & 3 & & & & & & 3 & 0,4 \\
\hline Cyclaneusma minus & & & & & & & & & & & & 2 & 5 & 1 & & 1 & & & 9 & 1,1 \\
\hline Cydalima perspectalis & & & & & & & & & & & & & & 1 & & & & & 1 & 0,1 \\
\hline Cynipidae & & 1 & & & 1 & & & & & & & & & & & & & & 2 & 0,2 \\
\hline Dasineura gleditchiae & & & & & & & & & & 1 & & & & & & & & & 1 & 0,1 \\
\hline $\begin{array}{l}\text { deformacija rasti po } \\
\text { škropljenju s FFS }\end{array}$ & & & & & & & & & & & & & & & & 1 & & & 1 & 0,1 \\
\hline Dioryctria sylvestrella & & & & & & & & & & & & & & & & 4 & & & 4 & 0,5 \\
\hline Diplodia pinea & & & & & & & & & & & & & & 1 & & 4 & & & 9 & 1,1 \\
\hline Discula destructiva & & & & & & & & & & & & & 1 & & & & & & 1 & 0,1 \\
\hline Dothistroma pini & & & & & & & & & 1 & & & & & & & & & & 1 & 0,1 \\
\hline Dothistroma septosporum & & & & & & & & 2 & & & & & 3 & & & 1 & & & 6 & 0,7 \\
\hline Drepanopeziza brunnea & & & & & & & & & & & & & & 5 & & & & & 5 & 0,6 \\
\hline Dryocosmus kuriphilus & & & & & & & & & & & & & 1 & & & & & & 1 & 0,1 \\
\hline Eriosoma lanuginosum & & & & & & & & & & & & & & & & 1 & & & 1 & 0,1 \\
\hline Erysiphaceae & & & & & & 2 & & 1 & & & & & 1 & & & 1 & & & 5 & 0,6 \\
\hline Erysiphe alphitoides & & 1 & 2 & 2 & 6 & 33 & 2 & 6 & 37 & & 12 & 27 & 17 & & & 30 & & & 175 & 20,4 \\
\hline Erysiphe arcuata & & & & & & 1 & & & & & & 1 & & & & 6 & & & 8 & 0,9 \\
\hline Erysiphe elevata & & & & & & & & & & & 3 & & 3 & 1 & & & & & 7 & 0,8 \\
\hline $\begin{array}{l}\text { Gymnosporangium } \\
\text { clavariiforme }\end{array}$ & & & & & & & & & & & & & 1 & & & & & & 1 & 0,1 \\
\hline Gymnosporangium sabinae & & & & & & & & & & & & & 1 & & & 1 & & & 2 & 0,2 \\
\hline $\begin{array}{l}\text { Gymnosporangium } \\
\text { tremelloides }\end{array}$ & & & & & & & & & & & & & 2 & & & & & & 2 & 0,2 \\
\hline Hymenoscyphus fraxineus & & & & & & & & & 1 & & & & 2 & & & 1 & & & 4 & 0,5 \\
\hline izpad ob presajanju & & & & & & & & & & & & & & & & 1 & & & 1 & 0,1 \\
\hline Kabatina thujae & & & & & & 1 & & 1 & & 2 & 1 & & 2 & 1 & 1 & & & & 9 & 1,1 \\
\hline Lecanosticta acicola & & & & & & & & & & & 1 & & 1 & & & 1 & & & 3 & 0,4 \\
\hline Leptostroma sp. & & & & & & & & & & & & 1 & & & & & & & 1 & 0,1 \\
\hline listne uši & & & & & & & & & & & & 2 & & & & & & & 2 & 0,2 \\
\hline Lophodermium seditiosum & & & & & & & & 1 & & & & & & & & & & & 1 & 0,1 \\
\hline Lophodermium sp. & & & & 1 & & 11 & & 3 & & & 4 & 8 & 17 & 2 & & 6 & & & 52 & 6,1 \\
\hline Lymantria dispar & & & & & & & & & 2 & & & & & & & & & & 2 & 0,2 \\
\hline Megaloseptoria mirabilis & & & & & & & & & & & & & & 1 & & & & & 1 & 0,1 \\
\hline mehanska poškodba & & & & & & & & & & & & & & & & 1 & & & 1 & 0,1 \\
\hline Melampsora populina & & 5 & & & & & & 1 & & & & & & 1 & & & & & 7 & 0,8 \\
\hline Melampsora populnea & & & & & & & & & & & & & & & & 1 & & & 1 & 0,1 \\
\hline Melampsora sp. & & & & & & & & & & & & & 1 & 4 & & & & & 5 & 0,6 \\
\hline Melampsoridium betulinum & & & & & & & & & & & & & 1 & & & & & & 1 & 0,1 \\
\hline $\begin{array}{l}\text { Melampsoridium } \\
\text { hiratsukanum }\end{array}$ & & & & & & & & & & & & & & & & 4 & & & 4 & 0,5 \\
\hline Melolontha melolontha & & & & & & & 1 & & & & & & & & & & & & 1 & 0,1 \\
\hline Mycosphaerella mori & & & & & & & & & & & & & 1 & & & & & & 1 & 0,1 \\
\hline Mycosphaerella pini & & & & & & & & 2 & & & 4 & 4 & 8 & & & 3 & & & 21 & 2,5 \\
\hline Nectria sp. & & & & & & & & & & & & & & & & 1 & & & 1 & 0,1 \\
\hline neznani povzročitelj & & & & & & & & & 1 & & 1 & & & & & 1 & & & 3 & 0,4 \\
\hline Neonectria ditissima & & & & & & & & & & & 1 & & & & & & & & 1 & 0,1 \\
\hline $\begin{array}{l}\text { Nothophaeocryptopus } \\
\text { gaeumannii }\end{array}$ & & & & & & & & & & & & & & & & 1 & & & 1 & 0,1 \\
\hline Oidium sp. & & & & & & & & & & & & 1 & & & & & & & 1 & 0,1 \\
\hline Otiorhynchus sulcatus & & & & & & & & & & & 2 & & & & & & & 2 & 4 & 0,5 \\
\hline $\begin{array}{l}\text { Paracercosporidium } \\
\text { microsorum }\end{array}$ & & & & & & 17 & & 3 & & & 8 & 14 & 5 & 3 & & 14 & & & 64 & 7,5 \\
\hline Paranthrene tabaniformis & & 11 & & & & & & & & & & & & 3 & & & & & 14 & 1,6 \\
\hline
\end{tabular}




\begin{tabular}{|c|c|c|c|c|c|c|c|c|c|c|c|c|c|c|c|c|c|c|c|c|}
\hline šo/ simptom & 1 & 2 & 3 & 4 & 5 & 6 & 7 & 8 & 9 & 10 & 11 & 12 & 13 & 14 & 15 & 16 & 17 & 18 & Skupaj & Skupaj $(\%)$ \\
\hline Parectopa robiniella & & & & & & & & & & & & 1 & & & & & & & 1 & 0,1 \\
\hline Pestalotiopsis sp. & & & & & & 1 & & & & & & & & & & & & & 1 & 0,1 \\
\hline Phloesinus aubei & & & & & & 6 & & & & & 2 & 1 & 3 & 2 & & & & & 14 & 1,6 \\
\hline Phomopsis juniperivora & & & & & & & & & & & 1 & & & & & 1 & & & 2 & 0,2 \\
\hline Phragmidium sp. & & & & & & & & 1 & & & & & & & & & & & 1 & 0,1 \\
\hline Phratora vitellinae & & 2 & & & & & & & & & & & & & & & & & 2 & 0,2 \\
\hline Phyllactinia guttata & & & & & 1 & & 1 & & & 1 & & & & & & & & & 3 & 0,4 \\
\hline Phyllaphis fagi & & & & & & & & & & & & & & & & 1 & & & 1 & 0,1 \\
\hline Phyllonorycter platani & & & & & & & & & & & 2 & & & & & & & & 2 & 0,2 \\
\hline Phyllonorycter robiniella & & & & & & & & & & & & 1 & & & & & & & 1 & 0,1 \\
\hline Phyllosticta paviae & & & & & & & & 2 & & & & & & & & & & & 2 & 0,2 \\
\hline Phytophthora ramorum & & & & & & & & 2 & & 1 & & & & & & & & & 3 & 0,4 \\
\hline Phytophthora sp. & & & & & & & & & & & & & 1 & & & & & & 1 & 0,1 \\
\hline Pissodes notatus & & & & & & & & & & & & & & & & 1 & & & 1 & 0,1 \\
\hline Pityogenes chalcographus & & & & & & & & 13 & & 12 & & 3 & 8 & & & 1 & & & 37 & 4,3 \\
\hline Plagiodera versicolor & & 1 & & & & & & & & & & & & 1 & & & & & 2 & 0,2 \\
\hline Polydrosus atomarius & & & & & & & & & & & 1 & & & & & & & & 1 & 0,1 \\
\hline Polydrosus sericeus & & & & & & & & & & & 1 & & & & & & & & 1 & 0,1 \\
\hline polži-obžiranje & & & & & & & & & & & & & 1 & & & & & & 1 & 0,1 \\
\hline Prociphilus fraxini & & & & & & & & & & & 1 & & & & & & & & 1 & 0,1 \\
\hline Rhabdocline laricis & & & & & & & & 1 & & & & & & & & 1 & & & 2 & 0,2 \\
\hline \begin{tabular}{|l|} 
Rhabdocline \\
pseudotsugae
\end{tabular} & & & & & & & & & & & & & 1 & & & & & & 1 & 0,1 \\
\hline Rhyacionia buoliana & & & & & & 1 & & 1 & & & & & 2 & 1 & & 2 & & & 7 & 0,8 \\
\hline Rhytisma acerinum & & & & & 2 & & & & & & & & 8 & & & & & & 10 & 1,2 \\
\hline Sacchiphantes sp. & & & & & & & 1 & 2 & & 1 & 4 & 3 & 9 & & & 4 & & & 24 & 2,8 \\
\hline Saperda populnea & & 11 & & & & & & & & & & & & 5 & & 1 & & & 17 & 2,0 \\
\hline Sawadaea bicornis & & & & & 2 & 6 & 1 & 1 & & 1 & & & 1 & 1 & & 6 & & & 19 & 2,2 \\
\hline Sawadaea tulasnei & & & & & & 1 & & & & & & & & & & 2 & & & 3 & 0,4 \\
\hline Scolytidae & & & & & & & 1 & 3 & & & 3 & 2 & 11 & 2 & & 2 & & & 24 & 2,8 \\
\hline Septoria corni & & & & 2 & & & & 4 & & & 2 & & & & & & & & 8 & 0,9 \\
\hline Sirococcus conigenus & & & & & & & & & & & & & 1 & & & & & & 1 & 0,1 \\
\hline Sphaerulina betulae & & & & & & & & & & & & & 1 & & & & & & 1 & 0,1 \\
\hline Stigmina carpophila & & & & & & & & 3 & & & 2 & 3 & & & & 1 & & & 9 & 1,1 \\
\hline sum na bolezen & & & & & & 1 & & & & & & 2 & 1 & & & & & & 4 & 0,5 \\
\hline Sydowia polyspora & & & & & & & & & & & & 1 & & & & & & & 1 & 0,1 \\
\hline Taphrina sp. & & & & & & & 1 & & & & & & & & & & & & 1 & 0,1 \\
\hline Taphrina tosquinetii & & & & & & & & & & & & & & & & 1 & & & 1 & 0,1 \\
\hline Tischeria ekebladella & & & & 1 & 1 & & & & 2 & & 1 & 1 & & & & & & & 6 & 0,7 \\
\hline toča & & 1 & & & & & & & & & & & & & & & & & 1 & 0,1 \\
\hline Tomicus sp. & & & & & & & & & & & & & & 1 & 1 & & & & 2 & 0,2 \\
\hline Truncatella hartigii & & & & & & & & & 1 & & & & 1 & & & & & & 2 & 0,2 \\
\hline Venturia inaequalis & & & 2 & & & & & & & & & & & & & & & & 2 & 0,2 \\
\hline vodni stres & & & & & & & & & & & & 2 & & & & & & & 2 & 0,2 \\
\hline zoocecidiji & & & & & & & & & & & 2 & & & & & & & & 2 & 0,2 \\
\hline Skupaj (N) & 0 & 47 & 4 & 9 & 15 & 102 & 10 & 61 & 54 & 24 & 70 & 115 & 148 & 41 & 4 & 151 & 0 & 2 & 856 & 100 \\
\hline Skupaj (\%) & 0,0 & 5,5 & 0,5 & 1,1 & 1,8 & 11,9 & 1,2 & 7,1 & 6,3 & 2,8 & 8,2 & 13,4 & 17,3 & 4,8 & 0,5 & \begin{tabular}{|l|c}
17,6 & $C$ \\
\end{tabular} & 0,0 & 0,2 & & 100 \\
\hline
\end{tabular}

